\title{
TRANSFERRING THE RESPONSIBILITY OF FOREST PROTECTION TO VILLAGE ADMINISTRATION: A CASE STUDY OF IKIZDERE, RIZE, TURKEY
}

\author{
AYAZ, H. ${ }^{1}-$ BILGILI, E. ${ }^{2 *}-$ KOROGLU, V. T. ${ }^{3}$ \\ ${ }^{1}$ Faculty of Law, Karadeniz Technical University, Trabzon, Turkey \\ ${ }^{2}$ Faculty of Forestry, Karadeniz Technical University, Trabzon, Turkey \\ ${ }^{3}$ Regional Forest Directorate, Trabzon, Turkey \\ *Corresponding author \\ e-mail: bilgili@ktu.edu.tr; phone: +90-506-661-2393; +90-462-377-7499
}

(Received $5^{\text {th }}$ Dec 2018; accepted $28^{\text {th }}$ Feb 2019)

\begin{abstract}
Effective public participation is considered essential to making sound decisions for the protection and sustainable management of natural resources. This paper aims to analyze the preferences of forest villagers to protect state forests within the boundaries of villages and generate income for their livelyhoods. As a case study area in Turkey, forest villages of Rize-Ikizdere town were selected to carry out the research. In the study area, intensive forest protection activities are carried out under the administration of Trabzon Regional Directorate of Forestry. A questionnaire form was developed and applied to the villages of the town on a face-to-face basis. According to the survey results, while most of the participants preferred to hand over the forest protection responsibility from state to legal village administration, they indicated some concerns about taking over the responsibility of forest protection that would bring some risks under the proposed policy. In conclusion, most of the participants envisioned that the new policy was likely to develop mutual understanding of participation, thoughtfulness, worthiness and stewardship about forests rather than foreseeing it as a source of income generation, and help lessen the forest degradation to a certain extent.
\end{abstract}

Keywords: public participation, natural resources, forest villagers, survey, conservation

\section{Introduction}

One of the basic objectives of all national forest policies include conservation with a focus on protection, maintenance, sustainable utilization, restoration and enhancement of the forested lands (Alemagi et al., 2013); however, meeting the objectives set by these policies has rarely been fully achieved (Makarabhirom, 1999). One of the impediments has been the lack of public participation in processes and mechanisms which enable stakeholders to be part of decision-making in all aspects of forest resource management, including policy formulation processes. Effective public participation is thus considered essential to making sound and better quality decisions about sustainable forest management (Beierle and Cayford, 2002; Buchy and Hoverman, 2000; Diaw et al., 2009; Kozak et al., 2008; Mendoza and Prabhu, 2000; MPWG, 1999; UNCSD, 1992; WCFSD, 1999) through which the socio-economical, ecological, and cultural values of the public can fully be taken into consideration regarding forest use and management (Buchy and Hoverman, 2000; Duinker, 1998; Pretty and Smith, 2004; Shindler and Neburka, 1997). This can be achieved by ecologically acceptable and socio-economically feasible approaches involving processes and mechanisms that enable stakeholders in forest resources to be part of decision-making in all aspects of 
forest management, including policy formulation (Cantiani, 2012; FAO, 2012 Kaskoyo et al., 2017).

Over the last several decades, public participation has become an important topic for environmental agencies throughout the world, and has been increasingly incorporated into forest management decision-making, with, in many cases, legal provisions for public input (Ahmed and Jana, 2017; Alemagi, 2007; Buchy and Hoverman, 2000; Cantiani, 2012; Coskun and Elvan, 2003; Duinker, 1998; Sinclair and Doelle, 2003). All these developments have been driven by pressures brought about by certain realities of ecology and economics and our increased demands for multiple use; expectations from and changing attitudes towards forests; and the need for the development of new policies and more effective management systems. The first examples of public participation in the management of forests were seen both in the developed and developing countries; however, objectives set and methodologies employed were different, due to the complex nature of the problems associated with the ownership of the lands and land use objectives.

In Canada and the US, for example, the onset of the participation process in as early as 1960 resulted in an increase in public awarenes of environmental issues among wider sections of the population (Cantiani, 2012; Germain et al., 2001; Grumbine, 1994; Tabbush, 2004; Vining and Tyler, 1999). Among other countries in Europe, Finland has been an important example in applying the effective and structured participation in forestry through establishing a number of working groups, represented by a wider range of people and the associated political parties to develop forest policies and prepare forestry related projects (Anonymus, 1995).

In some developing countries, public participation has been exercised in a more cohesive way and with more focus on the empowerment of local populations emphasising principles of equity and social justice (Cantiani, 2012). This approach assumes partial or full responsibility of local people in the management of resources within their jurisdictions. In this regard, a new concept of "Forest management by the village" in Tanzania (Warner, 1997), "Joint Forest management (JFM)" concept of India (Ahmed and Jana, 2017; SPMU, 2015), "Social Forestry Programme" of Nepal (Gimmour and Fisher, 1991) can be given as important examples.

Turkey also represents a similar and a unique example. Public participation is a major concern in the management of forest resources. With about seven million people living in about 20 thousand villages in and around forested lands, most forest villagers depend on forests for their livelihoods. Almost all forested lands (99.9\%) in the country belong to the state and are managed and protected by the General Directorate of Forestry (GDF). State policies for the protection of forestlands and natural resources have been developed with little emphasis on the needs, demands and expectations of society and forest communities. Although many different protection measures have been taken and implemented, including "forest soldiers" (Bingöl, 1990) and "centralized protection centers" (Ayanoglu, 1981), success has been limited. In the search for a better alternative, a method/policy that empowers the legal village administration to protect the forests within the boundaries of villages with a certain amount of budget and a bilateral protocol has been explored for some two decades now. However, there have been no comprehensive research endeavors, aside from some theoretical studies, documenting the pros and cons of handing over forest protection activities to the village administration compared to the current practices. It is quite uncertain how much benefit the alternative methods may provide to the forest villagers and to the sustainable 
management of the forest resources. Besides, the expectations, demands and preferences of the forest villagers would be unknown when the new protection policy would be in effect.

The objective of this research is to analyze the attitudes and preferences of forest villagers regarding the transfer of forest protection activities, currently conducted by the forest protection unit of the state forest organizations, to the legal entity of villages. The study also focuses on revealing the probability of success of the newly proposed approach in the eyes of the forest villagers. The forest villages of Rize-Ikizdere town were selected as a case study area. Here, the forests are intermingled with both residential areas and agriculture lands creating complex and intense forest protection activities.

\section{Material and methods}

The case study area is located between 40 57'12"- 40 $50^{\prime} 46^{\prime \prime} \mathrm{N}$ latitudes and $40^{\circ} 24^{\prime} 15^{\prime \prime}-40^{\circ} 55^{\prime} 07^{\prime \prime}$ E longitudes in the northeastern part of Turkey (Fig. 1). The total surface area of Ikizdere town within the province of Rize is about 89,800 ha, of which 29,698 ha $(33 \%)$ is forested. The population of Ikizdere, which is the highest of all the towns in Rize, was nearly 5,600 in $2017.68 \%$ of the population $(3,814)$ lives in the villages and the outskirts of Ikizdere town (URL-1, 2018). According to article 31 of Turkish Forest Law 6831, 24 villages of Ikizdere Town are in the status of "forest villages" that have certain privileges and status over other ordinary villages.

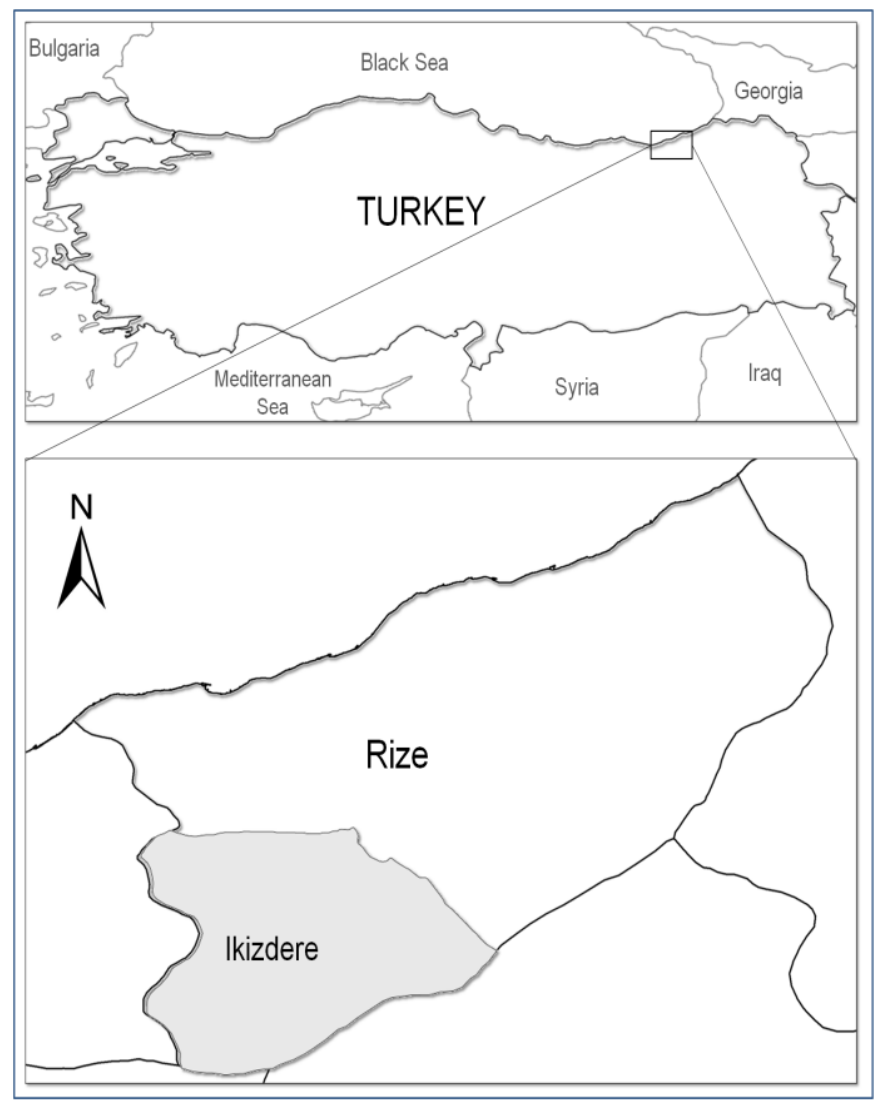

Figure 1. The geographic location of the case study area 
The research method employed in this study entailed the use of structured questionnaires administered in the forest villages located within the study area. The questionnaire form consisting of 12 structured questions was tested with an initial pilot application in the study area prior to the implementation of the study. As a result, the number of questions were reduced to eight and revised accordingly in the process. The individuals interviewed were selected with a simple random sampling method. The survey was conducted by one researcher in the field on a face-to-face interview basis. A total of 104 households from 24 potential forest villages were contacted for the interview. Only one person per household (the household representative) was interviewed to avoid repetition and achieve some level of consistency in answers from respondents of the same household (Asante et al., 2017). Four to five household representatives from each village were included in the study. The number of respondents required (sample size) in this study was calculated to be 96 using the formula (Eq.1):

$$
n=\frac{F \times t^{2} \times P \times Q}{\left(F \times m^{2}\right)+\left(t^{2} \times P \times Q\right)}
$$

where,

n: sample size

F: Population size

t: Confidence level $(95 \%)$

$\mathrm{m}$ : Margin of error $(10 \%)$

$\mathrm{P}$ and Q: Percentage value $(0,5 \times 0,5)$.

The questionnaire form was designed to acquire both personal information of forest villagers such as the number of individuals in the household, the age, education level of the respondents and the annual income of households, and other information in line with the objective of the study, such as the possibilities, advantages and disadvantages of transferring the rights of state forest protection activities to the forest villagers, as well as gathering the opinions of the villagers about the current status of forest protection. The questions of the survey were designed in the form of a series of closed-ended, single-choice questions. The respondents were asked to select one alternative among all alternatives provided within the survey form. In addition to the close-ended questions, the form also included an additional alternative under the heading of the "other" to allow the respondents to suggest different alternatives freely. The results of the survey were statistically analyzed using the Statistical Package for Social Scientists (SPSS version 16). The socio-economic and demographic characteristics of respondents were summarized and presented using simple descriptive statistics. Moreover, to see if there is a relationship between socio-economic and demographic characteristics of respondents and their choises, Chi-squared test was employed. In addition to the analysis of the questionnaire results, the qualitative data from the interviews was also evaluated to get the ideas and preferences of the respondents regarding the protection of the state forest resources.

\section{Results}

In this survey, two out of eight questions asked to the respondents were about the socio-economic and demographic structure of the villages. The rest of the questions were about the opinions and preferences of the respondents who were asked in order to select the method that people would see as appropriate. 


\section{Results about the households surveyed}

The results related to the number of individuals in the households, the age, educational level, annual income of households are listed in Table 1.

Table 1. The demographic information about the respondents interviewed and households surveyed

\begin{tabular}{c|c|c}
\hline \multicolumn{3}{|c}{ Individuals in a household } \\
\hline Person & Number & Percent \\
\hline $1-2$ & 19 & 18 \\
$3-4$ & 22 & 21 \\
$5-6$ & 34 & 33 \\
$>7$ & 29 & 28 \\
Total & 104 & 100 \\
\hline \multicolumn{3}{c}{ Age (year) } \\
\hline Year & Number & Percent \\
\hline $0-30$ & 6 & 6 \\
$31-50$ & 42 & 40 \\
$>50$ & 56 & 54 \\
Total & 104 & 100 \\
\hline \multicolumn{3}{|c|}{ Level of Education } \\
\hline Level & Person & Percent \\
\hline Lititerate & 5 & 5 \\
Elementary school & 1 & 1 \\
High school & 76 & 73 \\
University & 17 & 5 \\
Total & 5 & 100 \\
\hline
\end{tabular}

Table 2. Employment and the annual income level of the household per individual

\begin{tabular}{c|c|c}
\hline \multicolumn{2}{c}{ Occupation } & Percent \\
\hline Occupation $^{1}$ & Number & 25 \\
Worker & 26 & 8 \\
Officer & 8 & 58 \\
Private sector & 61 & 9 \\
Other & 9 & 100 \\
Total & 104 & Percent \\
\hline \multicolumn{2}{c}{ Annual income per person } \\
\hline Amount (\$) & Number of households & 54 \\
\hline $0-1000$ & 56 & 3 \\
$1001-2000$ & 2 & 41 \\
$2001-4000$ & 3 & 100 \\
$>4001$ & 43 &
\end{tabular}

${ }^{1}$ Worker: person working for a state organization as a worker; Officer: person employed by a state organization as a civil servant; Private sector: any person not employed by a state organization; Other: person retired or having no job. 
According to Table 1, there are primarily 6-7 individuals in a household and the average age of the household representatives is over 50 years. The literacy rate of the household representatives is about $95 \%$. This is almost the same as the average literacy rate of the country (96\%) (URL-2, 2018).

The survey included questions regarding the employment and the income level of the households. The type of employment and the salaries of the respondents were directly asked in the household survey. Additionally, where agriculture is not the main source of income, it was thought that income from agricultural activities would also be valuable to determine the total income of the households more realistically. Thus, the amount of agricultural products produced were included in the questions asked, and the results were processed with the current unit prices in order to determine the income level of the households. Table 2 shows the employment and the annual income level of the households. The US dollar currency of the date when the survey was conducted was used in the conversion.

About $54 \%$ of the households surveyed in this study has an annual income level under $1000 \$$ per person, indicating a monthly income of less than $100 \$$. The agricultural income is quite low due to the scarcity of agricultural land and the poor productivity of the land used for agricultural purpose. However, the presence of officers and workers in households helps increase the annual income level in the case study area. Some of the "private workers" are working only in agricultural activities and animal husbandry; the others are operators or small businesspersons in the town facilities or tourism facilities. The "other" category of occupation in Table 2 refers to the persons who are either housewife or jobless.

\section{Opinions of the household representatives about the forest and forestry}

In this category of the survey, five closed-ended questions were asked to the representatives of the household and the results were analyzed in the following subheadings.

\section{Who should protect the state forests?}

The appropriate choice among the possible alternatives for the protection of the state forests within their village boundaries was asked to the forest villagers. For that purpose, four alternative methods of forest protection were determined and placed into the survey. The first of the four alternatives in the questionnaire form refers to the current alternative of "continuation of the current method of forest protection (by the state forest sector)", the second alternative is about the "protection of forests by the civil authorities", the third one refers to the "forest protection by the squads of forest soldiers experienced in a certain period in the history of Turkish forestry" and the last one is the "protection of state forests by the villagers". The answers to these important questions are given in Table 3 .

Table 3. Alternative forest protection methods presented in the survey

\begin{tabular}{l|c|c}
\hline \multicolumn{1}{c|}{ Alternative methods for better protection of forests } & Number & Percent \\
\hline Forests should be protected by the state forest organizations & 47 & 45 \\
Forests should be protected by the legal village entities & 57 & 55 \\
Total & 104 & 100 \\
\hline
\end{tabular}


According to Table 3, the majority of the respondents (55\%) preferred the choice of forest protection by the forest villages. The rest of the respondents $(45 \%)$, however, favored the alternative of forest protection by the state forest organizations as currently practiced in Turkey. In fact, there was no significant difference between the two alternatives. Surprisingly, the other two alternatives (forest protection by the civilian authorities and forest protection by the squads of forest soldiers) developed in the survey form were not selected by the respondents at all. Aside from the four alternatives, no additional alternative was suggested by the respondents either.

\section{Evaluating the pros and cons of forest protection by the villages}

Table 4 presents the responses about the priority or degree of the possible consequences of transferring the state forest protection activities to the legal village entities.

Table 4. Benefits of transferring forest protection to the forest villages; first option: "Development of desire to safeguard the forest and increased feeling of affection for them"; second: "A decrease in forest related crimes, due to resulting self-control"; third: "Less illegal forest utilisation"; fourth: "Generation of additional income for the villagers

\begin{tabular}{lccc}
\hline \multicolumn{1}{c}{ Benefits of forest protection by forest villages } & Rank & Number & Percent \\
\hline $\begin{array}{l}\text { Develops the spirit for safeguarding and feeling of } \\
\text { affection for the forests. }\end{array}$ & 1 & 82 & 80 \\
Decreases forest related crimes as it brings self-control & 2 & 37 & 36 \\
Lessens illegal forest utilization. & 3 & 49 & 47 \\
Helps generate additional income for the villagers. & 4 & 75 & 72 \\
\hline
\end{tabular}

Based on the interpretation of Table 4, the majority of the respondents (80\%) believes that the principle benefit of forest protection by the forest villages would be the choice "develops the spirit for safeguarding and feeling of affection for the forests", that shows the level of forest stewardship. About 36\% of the respondents indicated that forest protection by the forest villages will cause decreases in forest related crimes as it brings self-control. The third priority benefit of forest protection by the forest villages is indicated by $47 \%$ of the respondents to be the "lessens illegal forest utilization". At the bottom of the priority list, $72 \%$ of the respondents indicated that forest protection by the forest villages will help generate additional income for the villagers.

On the other hand, potential disadvantageous of forest protection by the forest villages were also questioned in the study. The opinions and the concerns of the villagers were gathered in the survey as well. The results are presented in Table 5.

Table 5. Ranking the disadvantages of forest protection by the forest villages

\begin{tabular}{lccc}
\hline \multicolumn{1}{c}{ Disadvantages of forest protection by forest villages } & Rank & Number & Percent \\
\hline $\begin{array}{l}\text { Inefficiency in forest protection by the villagers may arise due to the lack } \\
\text { of knowledge about forest ecosystems in general. }\end{array}$ & 1 & 35 & 34 \\
$\begin{array}{l}\text { Disputes with neighboring villages or villagers may be inevitable and this } \\
\text { may fuel hostility, should village administrations take biased or }\end{array}$ & 2 & 64 & 62 \\
$\begin{array}{l}\text { prejudiced decisions. } \\
\begin{array}{l}\text { Severe confrontations may be indispensable in the election of chiefs for } \\
\text { the villages. }\end{array}\end{array}$ & 3 & 27 & 26 \\
Illegal forest utilization may increase. & 4 & 41 & 39 \\
\hline
\end{tabular}


According to Table 5, nearly $34 \%$ of the respondents indicated the most important concern about forest protection by the forest villages was "inefficiency in forest protection by the villagers may arise due to the lack of knowledge about forest ecosystems in general". The second important concern indicated by the $62 \%$ of the respondents is the possible "disputes with neighboring villages or villagers may be inevitable and this may fuel hostility, should village administrations take biased or prejudiced decisions". Of course, the chief or managers of forest village administration will become responsible and powerful with the initiation of forest protection by the villages. The candidates for the chief position may be confronted by serious challenges to get the rights and power of the village administration. Such situation may cause hostilities among the villagers. This concern is ranked third among the disadvantages of forest protection by the villages. Finally, 39\% of the respondents believed that "illegal forest utilization may increase" as a forth concern when forest protection activities are transferred to the forest villages.

Forest villagers' Expectations from the agreement between the state and the village administration upon the transfer of forest protection to forest villages

The opinions of the villagers were gathered in the survey in order to determine the conceivable expectations of forest villagers from the transfer of forest protection activities to forest villages. The results are summarized in Table 6.

Table 6. Expectations of forest villagers from the agreement upon the transfer of forest protection to forest villages

\begin{tabular}{lccc}
\hline \multicolumn{1}{c}{ Expectations } & Rank & Number & Percent \\
\hline $\begin{array}{l}\text { Social security coverage for the villagers working in forest } \\
\text { protection activities. }\end{array}$ & 1 & 95 & 91 \\
$\begin{array}{l}\text { Higher payments } \\
\text { Training of forest villagers who will work in forest protection } \\
\text { activities about the rights and the responsibilities. }\end{array}$ & 3 & 62 & 60 \\
$\begin{array}{l}\text { Provision of clothes, guns and other equipment to the forest } \\
\text { villagers in charge of forest protection }\end{array}$ & 4 & 57 & 55 \\
\hline
\end{tabular}

Table 6 shows that the most important expectation is the "covering of the villagers working in forest protection activities under social security programme." reflected by the $91 \%$ of the respondents in the survey. The second level of expectation is the high level of payment for the villagers who will work in forest protection activities. Training of forest villagers and provision of clothes, guns and other equipment to the forest villagers in charge of forest protection are among the latter expectations.

Evaluation of legal rights and responsibilities upon the transfer of forest protection to the forest villages

The villagers empowered with the rights to protect the forest resources need to know their legal rights and the responsibilities to carry out the activities effectively. The opinions and the concerns related to the legal rights and the responsibilities for the villagers are summarized in Table 7. 
Table 7. Results related to the legal rights and responsibilities of forest villages entitled to protect forest resources

\begin{tabular}{lcc}
\hline \multicolumn{1}{c}{ Evaluations by the forest villagers } & Number & Percent \\
\hline $\begin{array}{l}\text { Forest villages should be empowered with the same rights and } \\
\text { responsibilities of the current forest rangers. }\end{array}$ & 38 & 37 \\
$\begin{array}{l}\text { The duty of protection should exist, yet administrative and judicial } \\
\text { penalty provisions for forest related crime and lawbreakers still need to } \\
\text { be exercised by public officers. }\end{array}$ & 31 & 30 \\
$\begin{array}{l}\text { Forest villages and the forest rangers need to cooperate in enforcing the } \\
\text { penalties incurred for the incurred by lawbreakers. }\end{array}$ & 42 & 40 \\
$\begin{array}{l}\text { No legal rights regarding the about the administrative and judicial penalty } \\
\text { provisions should be granted to the forest villages }\end{array}$ & 6 & 6 \\
\hline
\end{tabular}

According to Table 7, forest villagers seem to abstain from undertaking legal rights and responsibilities for forest protection activities. Only $37 \%$ of the local people indicate their desire to empower the forest villages with the rights and responsibilities of the current forest rangers. Others either would like to cooperate with the public officers and do not want to get involved, as an intervener, in prescribing and enforcing the associated penalties for the lawbreakers.

\section{Opinions about causes of committing forest crimes or misconducts}

The fundamental causes of committing forest crimes in state forests in the eyes of forest villages are evaluated here. While four different questions were designed and asked to the forest villagers in the survey, only two of them were responded appropriately.

Table 8. The results and the rates of the causes of committing forest crimes

\begin{tabular}{lcc}
\hline \multicolumn{1}{c}{ The causes of committing forest crimes } & Number & Percent \\
\hline Inadequacy of the recruited forest rangers & 5 & 5 \\
Poverty of forest villagers & 99 & 95 \\
Total & 104 & 100 \\
\hline
\end{tabular}

Table 8 clearly shows that the fundamental cause of forest related crimes or misconducts is apparently the poverty of the forest villagers $(95 \%)$. The inadequacy of the recruited forest rangers is only represented by $5 \%$ of the respondents. However, the alternatives of "attitude to gain improper personal benefit" and "desire to proclaim forest land for agricultural activities" were not selected by the respondents at all. While there was the "other" alternative for the respondents to provide further causes of forest crime, it was left blank.

\section{Discussion}

This paper highlights the preferences of forest villagers to protect state forests within the boundaries of villages in the northeastern part of Turkey. It also outlines the perceptions of the local people in public participation and identifies challenges in forest protection in Turkey. The study is limited in terms of coherence and extent, but 
provides new perceptions in forest protection in state-owned forests. Almost all forests are owned by the state in Turkey, and General Directorate of Forestry (GDF is the primary state organization in the country responsible for both managing the forest resources including all forest related actions and patrolling the forest lands and protecting its properties against any illegal activities in all forests across the country. The forest protection activities have long been carried out by the forest rangers established by the state forest sector for over 60 years. While the forest crimes in the country have decreased for the last three decades, more than 120,000 forest misconducts have been registered over the last decade (2008-2017). The number of forest misconducts in 2016 alone constituted nearly 10,000 cases according to the official reports (GDF, 2016). Moreover, it is suspected that majority of forest misconducts have not been reported and registered in the official records, indicating an inadequacy in overall protection activities.

The questionnaire administered in the selected case study areas identified both demographic status of the respondents and the opinions and expectations of forest villagers about the transfer of the authority in forest protection to the villages as per an agreement between the state and the village administration. According to the survey results, the literacy level of the people and the size of the household in the case study area were found to be close to the country averages (URL-2, 2018). When the income is evaluated, nearly $55 \%$ of the people has an annual income of less than 1,000\$ per individual. However, the annual income per individual is considerably higher in households having public officers and private job owners such as salesmen or small entrepreneurs.

People living in the forest villages consider that the primary reason for committing a forest crime in state forests around villages is the poverty in rural areas. Only the $5 \%$ of the respondents indicated that forest destruction is realized due to inadequacies or vicious attitudes of the forest rangers authorized in forest protection activities. These results are in agreement with poverty related forest crimes in the developing countries (ATIF). Forest management and protection programmes through participation have mostly been developed in response to both high number of forest crimes and the reality of the forest villagers being among the poorest people of the country (UNCSD, 1992; Duinker, 1998; WCFSD, 1999; MPWG, 1999; Buchy and Hoverman, 2000; Coskun and Elvan, 2003; Pretty and Smith 2004; Alemagi, 2007; Kozak et al., 2008; Cantiani, 2012). In this regard, public participation in forest management may be an important step towards the sustainable use and protection of forest resources (Alemagi, 2007; Kozak et al., 2008; Diaw et al., 2009; Cantiani, 2012; Ahmed and Jana, 2017). One of the practical alternatives seems to be the transfer of the forest protection activities to the forest villagers under certain provisions as suggested in this study. Such that, forests would be protected more effectively than previously and there would be a relative increase in the income of forest villagers.

Almost $45 \%$ of forest villagers involved in the survey favored the maintenance of current operation or method in forest protection. However, the majority preferred the transfer of forest protection authority to the villages. The contract of forest protection can be considered to be a source of income particularly for the unemployed villagers or the households involved in agriculture and animal husbandry. As a matter of fact, almost $70 \%$ of the respondents expects that the annual income of the forest villagers will considerably increase due to the contract of the forest protection taken by the villages. Several programmes implemented in many countries provided evidences to 
support this conclusion (Kozak et al., 2008; Vergara-Asenjo and Potvin 2014; Kaskoyo et al., 2017; Ahmed and Jana, 2017). The results also indicate that additional sources of income may be generated for the common expenses of the villages such as roads, bridges, mosques and common village mansions. In addition to additional source of income for individuals and fund raising for common village expenses, it was understood with $80 \%$ of acceptance level that the protection of forest lands by forest villages would enhance the relationships between people and their forest, internalize the proposed forest management concept and help increase an interest in forests. Additionally, Table 6 indicated that forest villagers authorized in forest protection activities would like to have payment and social security covered by the new alternative as they work in state forest management endeavors. These findings are in close agreements with other reports. In Panama, for example, it was reported that public participation and the provision of additional sources of income (Vergara-Asenjo and Potvin, 2014) and increased use of state forests by the villagers would increase the success in forest protection (Thang et al., 2010). Moreover, these provisions may foster and lead to the acceptance of new rights for the poor forest villagers (Scheba and Mustalahti, 2015).

Surprisingly, the assumption that the number of unaccounted and of reported forest crimes may be lowered as a result of transferring the forest protection activities to the forest villages due to self-control was not favored by the majority of the respondent forest villagers. Even, as seen in Table 5, almost 39\% of the villagers showed a deep concern about the possible increase in illegal forest utilization. Besides, clothes, guns and other equipment was also requested for the forest villagers in charge of forest protection.

Forest villagers taking part in the survey are doubtful about fulfilling appropriately or enforcing the duty of forest protection given to them. Almost $57 \%$ of the forest villagers would like to be trained by the state forest organizations on the expected rights and the responsibilities. Trainings were reported to improve the succes of such programmes (Kaskoyo et al., 2017). In contrast to that, only $37 \%$ of the forest villagers thinks that they would be able to enforce the duty of forest protection if the related legal basis is established. The majority would like to cooperate with the public officers to conduct forest protection activities and indicated that administrative and judicial penalty provisions for the forest related crime and the lawbreakers still need to be exercised by the public officers.

The forest villagers show serious concerns about possible confrontations with neighboring villages as well as with their own during the prevention of forest crimes and struggle with lawbreakers. Furthermore, people worry about the fact that the challenge may spark off undesired confrontations among households during the elections for the village administration.

As for the relationship between socio-economic and demographic status of the respondents and protection alternatives, Chi-squared statistic did not reveal any significant relationships between the responses of villagers and the socio-economic and demographic variables. However, although not statistically significant, unlike expectations, results indicated that older people were more of the opinion that protection activities should be transferred to villages. This can be ascribed to the fact that young people have a tendency to move to metropolitan areas to find better job opportunities. The results also indicated a parallelism in the tendency of forest protection by the villagers as the number of households increase. 


\section{Conclusions}

General conclusions reached can be summarised as:

- Villagers, in general, seem to be ambitious and prepared to use the rights and shoulder the responsibilities for the protection of forests within the boundaries of their villages with a certain amount of negotiated budget and a bilaterally agreed protocol.

- Most of the participants in the survey envisioned the new policy proposal to provide some opportunities to develop mutual impressions about participation, thoughtfulness, worthiness and stewardship in forest protection and, to a lesser extent, generate a source of income.

- Training is necessary for the successful implementation of the proposed program. In this regard, villagers who will take part in forest protection activities need to be trained systematically about the due rights and responsibilities. And,

- An effective administrative controlling process seems to be inevitable. State forest administration should continue to cooperate with the forest villagers in struggling with the forest lawbreakers as well as preventing any conceivable prejudiced decisions of the villagers and likely corruptions. It is also crucial and necessary that the state forest organizations enforce the duty of both administrative and judicial penalty provisions for the forest related crimes.

- Transferring the forest protection activities to the forest villages is considered timely and necessary in Turkish forestry provided that the required precautions are taken and some cases are designed and implemented in pilot areas to foresee any possible complications and problems, before the widespread implementation of the approach across the country.

- Given the area studied and issues contained in the study, this study can be considered extremely limited. Community involvement in any planning requires that local conditiones be also included in the overall planning process. Therefore, new studies are required for other regions before a wisespread implementation of the proposed program. The new studies should involve socio-economical, physical, ecological aspects of community involvement in future forest management plannings.

\section{REFERENCES}

[1] Ahmed, M. U., Jana, S. K. (2017): Role of Joint Forest Management (Jfm) in Improving the Living Standard of Rural People: Some Case Studies in West Bengal in India. International Journal of Human Resource Research Review 5: 16-26.

[2] Alemagi, D. (2007): The oil industry along the Atlantic Coast of Cameroon: Assessing impacts and possible solutions. - Resource Policy 32: 135-145.

[3] Alemagi, D., Hajjar, R., Tchoundjeu, Z., Kozak, R. (2013): Cameroon's Environmental Impact Assessment Decree and Public Participation in Concession-Based Forestry: An Exploratory Assessment of Eight Forest-Dependent Communities. - Journal of Sustainable Development 6: 8-24.

[4] Anonymus (1995): Sustainable Develepment of Switzerland's Forest, Federal Office of Environment. - Forest and Landscape (FOEFL) Swiss Forest Agency, Berne: 37.

[5] Asante, W. A., Acheampong, E., Boateng, K., Adda, J. (2017): The implications of land tenure and ownership regimes on sustainable mangrove management and conservation in 
two Ramsar sites in Ghana - Forest Policy and Economics 85(1): 65-75. https://doi.org/10.1016/j.forpol.2017.08.018

[6] Ayanoglu, S. (1981): Atatürk Dönemi Ormancılık İlkeleri Işığında Günümüz Ormancılığının İncelenmesi, Doğumunun 100. Yılında Atatürk'e Armağan. - İstanbul Üniversitesi Yayın No: 2883, Orman Fakültesi Yayını: 307, Fakülteler Matbaası, Istanbul.

[7] Beierle, C. T., Cayford, J. (2002): Democracy in Practice: Public Participation in Environmental Decisions. - Resources for the Future: 149.

[8] Bingöl, İ. (1990): Geçmişten Günümüze Ormanlarımız ve Ormancılığımız. - Cillt I, Ormancılık Eğitim ve Kültür Vakfı, Matbaa Teknisyenleri Basın Evi, Yayın No: 3, Istanbul.

[9] Buchy, M., Hoverman, S. (2000): Understanding public participation in forest planning: a review. - Forest Policy Econ 1: 15-25.

[10] Cantiani, M. G. (2012): Forest planning and public participation: a possible methodological approach. - Iforest 5: 72-82.

[11] Coskun, A. A., Elvan, D. O. (2003): Urgent Amendments on Turkish Forest Legislation Concerning Participation. - XII World Forestry Congress, Quebec City.

[12] Diaw, M. C., Prabhu, R., Aseh, T. (2009): Assembling the ACM mosaic: reflection and conclusion, In Search of Common Ground: Adaptive Collaborative Management in Cameroon. - Center for International Forestry Research, Bogor, Indonesia: 444-475.

[13] Duinker, P. (1998): Public participation's promising progress: advances in forest decision-making in Canada. - Commonw Forest Rev 77: 107-112.

[14] FAO (2012): Community-based forestry. - http://www.fao.org/forestry/participatory/en/ Accessed on: 07.08.2018

[15] GDF (2016): Forestry Statistics - https://www2.ogm.gov.tr/ Accessed on:12.03.2018.

[16] Germain, R. H., Floyd, D. W., Stehman, S. V. (2001): Public perceptions of the USDA Forest Service public participation process. - Forest Policy Econ 3: 113-124.

[17] Gimmour, D. A., Fisher, R. J. (1991): Villagers, Forests and Foresters: The philosophy, Process and Practice of Community Forestry in Nepal. - Sahayogi Press, Kathmandu, Nepal: 212.

[18] Grumbine, R. E. (1994): What Is Ecosystem Management? - Conserv Biol 8: 27-38.

[19] Kaskoyo, H., Mohammed, A.J., Inoue, M. (2017): Impact of Community Forest Program in Protection Forest on Livelihood Outcomes: a Case Study of Lampung Province, Indonesia. - Journal of Sustainable Forestry (accepted), DOI: 10.1080/10549811.2017.1296774

[20] Kozak, R. A., Spetic, W.C., Harshaw, H. W., Maness, T. C., Sheppard, S. R. J. (2008): Public priorities for sustainable forest management in six forest dependent communities of British Columbia. - Canadian Journal of Forest Research-Revue Canadienne De Recherche Forestiere 38: 3071-3084.

[21] Makarabhirom, P. (1999): Case Study of Forest Law Enforcement in Thailand. - Paper presented at the Mekong Basin Countries Symposium on Forest Law Enforcement held in Phnom Penh, Cambodia: 101-109.

[22] Mendoza, G. A., Prabhu, R. (2000): Multiple criteria decision making approaches to assessing forest sustainability using criteria and indicators: a case study. - Forest Ecol Manag 131: 107-126.

[23] MPWG (1999): The Montreal process: criteria and indicators for the conservation and sustainable management of temperate ad boreal forests (2nd ed.). - Ottawa: Montreal Process Liaison Office.

[24] Pretty, J., Smith, D. (2004): Social capital in biodiversity conservation and management. - Conserv Biol 18: 631-638.

[25] Scheba, Andreas., Mustalahti, I. (2015): Rethinking 'expert' knowledge in community forest management in Tanzania. - Forest Policy and Economics 60: 7-8. https://doi.org/10.1016/j.forpol.2014.12.007 
[26] Shindler, B., Neburka, J. (1997): Public participation in forest planning: eight attributes of success. - J Forest 95: 17-19.

[27] Sinclair, A. J., Doelle, M. (2003): Using law as a tool to ensure meaningful public participation in environmental assessment. - Journal of environmental law and practice 12: $27-54$

[28] SPMU (2015): Joint Forest Management (JFM) Handbook. - New Delhi, Department of Forests, Government of Madhya Pradesh, JPS Associates (P) Ltd.: 186.

[29] Tabbush, P. (2004): Public money for public good? Public participation in forest planning. - Forestry 77: 145-156.

[30] Thang, T. N., Shivakoti, P., Inoue, M. (2010): Changes in Property Rights, Forest Use and Forest Dependency of Katu Communities in Nam Dong District, Thua Thien Hue Province, Vietnam. - International Forestry Review 12(4): 307-319.

[31] UNCSD (1992): Non-legality binding authoritative statement of principles for a global consensus on the management, conservation and sustainable development of all types of forests, Annex III to the Report of the United Nations Conference on the Environment. United Nations Department of Economic and Social Affairs (DESA), Rio de Janeiro.

[32] URL-1 (2018): Website on Participatory Forestry - Retrieved from: http://www.nufusune.com/ikizdere-ilce-nufusu-rize. Accessed on: 04.10.2018.

[33] URL-2, (2018): Statistics of Turkey. Turkish Statistical Institute - Retrieved from: https://biruni.tuik.gov.tr/yayin/views/visitorPages/index.zul. Accessed on: 04.10.2018.

[34] Vergara-Asenjo, G., Potvin, C. (2014): Forest protection and tenure status: The key role of indigenous peoples and protected areas in Panama. - Global Environmental Change 28: 205-215. https://doi.org/10.1016/j.gloenvcha.2014.07.002

[35] Vining, J., Tyler, E. (1999): Values, emotions and desired outcomes reflected in public responses to forest management plans. - Research in Human Ecology and Evolution 6: 21-34.

[36] Warner, K. (1997): Toplum Ormancılığının Sürdürülebilir Kalkınmadaki Vizyonu ve Rolü. - XI. Dünya Ormanc1lık Kongresi, Ekim, Ankara, Bildiriler Kiatb1 5: 53-65.

[37] WCFSD (1999): Our forest, our future: Report of the World Commission on Forest and Sustainable Development. - Cambridge: Cambridge University Press. 


\section{The interviewee:}

\section{Questionnaire}

Age:

Educational status:

Occupation:

Number of population in the household:

2. Total annual income of the household:

I. Salary: (for employees)....................................... \$/year

ii. Agricultural income: ................................ \$/year

iii. Livestock income:.................................. \$/year

iv. Other incomes (self-employment):.................... \$/year

\section{Alternative forest protection methods presented in the survey}

a. Forests should be protected by the state forest organizations

b. Forests should be protected by local governors

c. Forests should be protected by troops

d. Forests should be protected by the legal village entities

e. other (please specify

\section{Benefits of forest protection by forest villages}

a. Develops the spirit for safeguarding and feeling of affection for the forests

b. Decreases forest related crimes as it brings self-control

c. Lessens illegal forest utilization.

d. Helps generate additional income for the villagers.

e. other (please specify

\section{Disadvantages of forest protection by forest villages?}

a. Inefficiency in forest protection by the villagers may arise due to the lack of knowledge about forest ecosystems in general.

b. Disputes with neighboring villages or villagers may be inevitable and this may fuel hostility, should village administrations take biased or prejudiced decisions.

c. Severe confrontations may be indispensable in the election of chiefs for the villages.

d. Illegal forest utilization may increase.

e. other (please specify

6. Expectations of forest villagers from the agreement upon the transfer of forest protection to forest villages

a. Social security Coverage for the villagers working in forest protection activities.

b. Higher payments

c. Training of forest villagers who will work in forest protection activities about the rights and the responsibilities.

d. Provision of clothes, guns and other equipment to the forest villagers in charge of forest protection

e. other (please specify ..) 


\section{Results related to the legal rights and responsibilities of forest villages entitled to protect forest resources.}

a. Forest villages should be empowered with the same rights and responsibilities of the current forest rangers.

b. The duty of protection should exist, yet administrative and judicial penalty provisions for forest related crime and lawbreakers still need to be exercised by public officers.

c. Forest villages and the forest rangers need to cooperate in enforcing the penalties incurred for the incurred by lawbreakers.

d. No legal rights regarding the about the administrative and judicial penalty provisions should be granted to the forest villages

e. other (please specify

\section{What are the main reasons for forest crimes?}

a. Easy and unfair gain

b. Inadequacy of the recruited forest rangers

c. Efforts to provide new agricultural areas

d. Poverty of forest villagers

e. Other (Please specify 